\title{
Persepsi Masyarakat Terhadap Pernikahan Dini Di Kecamatan Muara Padang Kabupaten Banyuasin
}

\author{
Nina Damayati1), Nurul Mardiyanti2)* \\ 1,2)Pendidikan Geografi, Fakultas Keguruan dan Ilmu Pendidikan, Universitas PGRI \\ Palembang, Indonesia
}

Diterima Februari, 2020; Disetujui April, 2020; Dipublikasikan Juni , 2020 \begin{abstract}
Abstrak
Pernikahan usia dini merupakan pernikahan yang dilakukan pada usia di bawah 18 tahun, Pernikahan yang tidak memiliki kesiapan fisik, mental dan materi akan menimbulkan banyak masalah terhadap rumahtangga yang menikah dini tesebut. Permasalahan pernikahan usia dini dan dampaknya banyak ditemukan di daerah Kecamatan Muara Padang Kabupaten Banyuasin, hal inilah yang membuat peneliti tertarik untuk melakukan penelitian di Kecamatan Muara Padang. Metode penelitian yang digunakan oleh peneliti yaitu metode deskriptif kualitatif dengan tujuan untuk mengetahui persepsi masyarakat terhadap pernikahan usia dini. Teknik pengumpulan data menggunakan wawancara, observasi, dan dokumentasi. Sedangkan untuk teknik pengambilan sampel mengunakan teknik Purposive Sampling maka didapat Informan kepala desa, petugas pencatat nikah, kepala Kantor Urusan Agama Kecamatan Muara Padang, dan responden yang menjadi pelaku pernikahan dini beserta orang tua pelaku yang melakukan pernikahan. Analisis data dilakukan dengan mempersiapkan dan mengolah data untuk dianalisis, membaca keseluruhan data, menganalisis lebih detail dengan meng-coding data, deskripsi dan tema-tema disajikan dalam laporan kualitatif, menginterpretasi atau memaknai data. Hasil penelitian yang didapatkan mengenai persepsi masyarakat terhadap pernikahan dini yang ada di Kecamatan Muara Padang Kabupaten Banyuasin menyatakan bahwa mayoritas masyarakat kurang setuju jika suatu pernikahan dilakukan di usia dini. Namun demikian hal tersebut masih saja terjadi karena kurangnya pendidikan, kesulitan ekonomi dan sebagian dikarenakan tradisi yang ada dilingkungan masyarakat tersebut.
\end{abstract}

Kata Kunci: Persepsi, Masyarakat, Pernikahan Dini

\begin{abstract}
Early marriage is a marriage that is carried out at the age of under 18 years. Marriage that does not have physical, mental and material readiness will cause many problems for households that get married early. The problem of early marriage and its effects are found in the Muara Padang Subdistrict, Banyuasin District, this is what makes researchers interested in conducting research in Muara Padang District. The research method used by researchers is a qualitative descriptive method with the aim to determine people's perceptions of early marriage. Data collection techniques using interviews, observation, and documentation. As for the sampling technique using the Purposive Sampling technique, informants were obtained by the village head, the marriage registrar, the head of the Religious Affairs Office in Muara Padang District, and the respondents who were the perpetrators of early marriage along with the parents of the perpetrators who married. Data analysis is done by preparing and processing data to be analyzed, reading the entire data, analyzing in more detail by coding data, descriptions and themes presented in qualitative reports, interpreting or interpreting data. The results of the study obtained regarding community perceptions of early marriage in Muara Padang District, Banyuasin Regency, stated that the majority of the community disagreed if a marriage was conducted at an early age. However, this still happens due to lack of education, economic difficulties and partly due to the traditions that exist in the community.
\end{abstract}

Keywords: Perception, Society, Early Marriage

How to Cite: Damayati, Nina \& Mardiyanti, Nurul. (2020). Persepsi Masyarakat Terhadap Pernikahan Usia Dini di Kecamatan Muara Padang Kabupaten Banyuasin. PUBLIKAUMA: Jurnal Ilmu Administrasi Publik, UMA, Vol 8 (1): 24-31

${ }^{*}$ Corresponding author: ISSN 2549-9165 (Print)

E-mail: nina.damayati91@gmail.com ISSN 2580-2011 (Online) 


\section{PENDAHULUAN}

Di Indonesia perkawinan di atur dalam undang-undang perkawinan no.1 tahun 1974, dalam hal ini perkawinan diartikan sebagai ikatan lahir batin antara laki-laki dan perempuan sebagai suami dan istri dengan tujuan membentuk keluarga yang bahagia dan tentram. Batas umur menikah yang terkandung dalam undang-undang tersebut perempuan minimal berusia 16 tahun dan lakilaki minimal 19 tahun. Ada beberapa negara menetapkan usia minimum menikah yang lebih rendah dibandingkan Indonesia: misalnya, di Iran anak laki-laki diizinkan untuk menikah pada usia lima belas, dan anak perempuan pada usia tiga belas tahun. Indonesia mengizinkan anak laki-laki menikah pada usia sembilan belas tahun, dan anak perempuan berusia enam belas tahun, sedangkan di Bahrain anak laki-laki diizinkan pada usia delapan belas tahun, dan anak perempuan berusia lima belas tahun (Council of Foreign Relations, 2013).

Batasan usia menikah yang ada di Indonesia bertantangan dengan undangundangan perlindungan anak yang menyatakan batas usia anak ialah 18 tahun, ini berarti jika mengizinkan anak menikah dibawah usia 18 tahun berarti mengizinkan pernikahan anak atau pernikahan usia dini. Ada banyak sekali dampak negatif yang ditimbulkan dari pernikahan usia dini.

Rumah tangga yang menikah usia dini dalam usia pernikahan kurang dari lima tahun berpotensi 39\% bercerai dan jumlah tersebut bisa terus bertambah mengingat usia pernikahan masih kurang dari lima tahun (Damayati. 2013). Selain perceraian ada banyak dampak lain yang ditimbulkan seperti kemiskinan, rendahnya tingkat pendidikan, kekerasan dalam rumah tangga, dan tingkat kesehatan juga rendah. Pernikahan dan kehamilan pada usia belia berkaitan dengan kondisi-kondisi yang serba merugikan, seperti rendahnya tingkat pendidikan wanita, rendahnya tingkat partisipasi kerja wanita, serta pendapatan keluarga yang rendah (Grogger \& Bronars, 1993). Perkawinan usia dini juga berdampak pada rendahnya kualitas keluarga, baik ditinjau dari ketidaksiapan secara psikis dalam menghadapi sosial ekonomi rumah tangga, resiko tidak siap mental untuk membina perkawinan dan menjadi orang tua yang bertanggung jawab, kegagalan perkawinan (Wilopo, 2005).

Berdasarkan laporan UNICEF dalam (PAI, 2018) Indonesia merupakan negara dengan angka perkawinan anak tertinggi ketujuh di dunia yaitu 457,6 ribu perempuan usia 20-24 tahun yang menikah sebelum berusia lima belas tahun. Pada level ASEAN, Indonesia berada di urutan kedua terbanyak setelah Kamboja. Sedangkan menurut BKKBN dalam level Nasional Provinsi Sumatera Selatan pada tahun 2013 berada pada urutan kesembilan dengan jumlah pernikahan usia dini terbanyak di Indonesia. Dilihat dari pernyataan tersebut bahwasannya pernikahan dini banyak sekali terjadi, terutama daerah yang aksesbilitas rendah, tingkat kemiskinan masih tinggi, tingkat pendidikan rendah, dan masih banyak faktor lain yang mempengaruhi pernikahan usia dini.

Faktor yang berpengaruh terhadap pernikahan usia dini ialah hamil sebelum nikah, status ekonomi orang tua, dan tingkat pendidikan (Damayati, 2016).Selain beberapa faktor diatas ada banyak dampak negatif yang muncul dari pernikahan usia dini seperti kemiskinan meningkat, kekerasan meningkat, belum bisa untuk mengontrol emosi dan masih banyak dampak lainnnya. Data profil anak di Indonesia pada tahun 2018 menunjukan adanya hubungan yang erat antara tingkat pendidikan dengan status perkawinan. Perbedaan status perkawinan dan pendidikan yang ditamatkan antara anak yang tinggal di perkotaan dan di perdesaan. Permasalahan anak yang tinggal di desa lebih tinggi, dilihat dari jumlah anak yang tidak pernah sekolah dan tidak tamat SD dengan status kawin dan cerai yang lebih tinggi bila di bandingkan dengan anak yang tinggal di kota hal ini menunjukan pernikahan usia dini masih banyak terjadi di daerah pedesaan.

Kasus pernikahan usia dini di Kecamatan Muara Padang cukup banyak hal itu dapat dilihat dari data jumlah pernikahan di Kecamatan Muara Padang pada periode Agustus - Desember tahun 2018 dengan usia menikah antara umur 16 - 20 tahun untuk perempuannya sebesar $39,6 \%$ sedangkan untuk laki-lakinya sebesar 9,38\% dari 96 pernikahan. Berdasarkan data tersebut menyatakan rata-rata dari seluruh jumlah kejadian pernikahan di Kecamatan Muara Padang sebanyak 24,5\% dalam kategori 
pernikahan dini. Dari latar belakang permasalahan tersebut peneliti tertarik untuk melakukan penelitian dengan tu juan melihat persepsi masyarakat terhadap pernikahan usia dini.

\section{METODE PENELITIAN}

Metode Penelitian yang digunakan dalam penelitian ini yaitu metode deskriptif kualitatif yang bertujuan untuk melihat lebih dalam persepsi masyarakat tentang pernikahan usia dini di Kecamatan Muara Padang. Teknik pengumpulan data menggunakan wawancara, observasi, dan dokumentasi. Sedangkan untuk teknik pengambilan sampel mengunakan teknik Purposive Sampling maka didapat Informan sebagai berikut:

Tabel 1. Jumlah Informan atau Responden

\begin{tabular}{|l|l|c|}
\hline No & \multicolumn{1}{|c|}{$\begin{array}{c}\text { Jenis Informan } \\
\text { /Responden }\end{array}$} & Jumlah \\
\hline 1 & Informan Kunci & Orang \\
\hline 2 & $\begin{array}{l}\text { Anak yang menikah usia } \\
\text { dini }\end{array}$ & 15 Orang \\
\hline 3 & $\begin{array}{l}\text { Orang Tua anak yang } \\
\text { menikah usia dini }\end{array}$ & 40 orang \\
\hline \multicolumn{2}{|l|}{ Jumalah Informan } \\
\hline
\end{tabular}

Sumber: Data Primer 2019

Pengumpulan data primer dilakukan dengan cara wawancara dan observasi dengan terjun langsung ke lapangan dan bertemu dengan para pelaku pernikahan usia dini, orang tua yang anaknya menikah usia dini dan beberapa toko masyarakat dan pejabat yang berwenang. Sedangkan untuk pengumpulan data sekunder dilakukan dengan cara mendatangi instansi yang berkaitan dengan data penelitian seperti kantor urusan agama, dan catatan nikah yang ada dikantor kepala desa.

Pengelolahan data dilakukan melalui proses penafsiran dan penyimpulan data dilakukan dengan mempersiapkan dan mengolah data untuk dianalisis, membaca keseluruhan data, menganalisis lebih detail dengan meng-coding data, menerapkan proses coding, deskripsi dan tema-tema disajikan dalam laporan kualitatif, menginterpretasi atau memaknai data.

\section{HASIL DAN PEMBAHASAN}

Penelitian ini dilaksanakan di Kecamatan Muara Padang Kabupaten Banyuasin. Kabupaten Banyuasin dimana yang memiliki Luas wilayah 11.832,99
$\mathrm{Km}^{2}$. Sedangkan untuk Kecamatan Muara Padang sendiri yang luas wilayahnya memiliki 3,782.01 $\mathrm{Km}^{2}$ dengan memiliki keadaan topografi wilayah sebagian besar terdiri dari dataran rendah, hutan rawa dan terdapat sungai buatan yang memisahkan antar desa.

Tabel 2. Jumalah Desa di Kecamatan Muara Padang

\begin{tabular}{|l|l|}
\hline No & Nama Desa \\
\hline 1 & Muara Padang \\
\hline 2 & Karang Anyar \\
\hline 3 & Tanjung Baru \\
\hline 4 & Margo Mulyo 20 \\
\hline 5 & Purwodadi \\
\hline 6 & Sumber Makmur \\
\hline 7 & Sido Mulyo 18 \\
\hline 8 & Air Gading \\
\hline 9 & Tirto Raharjo \\
\hline 10 & Marga Sugihan \\
\hline 11 & Sidorejo \\
\hline 12 & Sidomulyo 20 \\
\hline 13 & Daya Makmur \\
\hline 14 & Daya Utama \\
\hline 15 & Tirta Jaya \\
\hline
\end{tabular}

Sumber: Data Primer 2019

Dari 15 desa yang ada Kecamatan Muara Padang tersebut ditemukan tiga desa yang melakukan pernikahan dini yang didapatkan dari buku registrasi pernikahan di Kecamatan Muara Padang Kabupaten Banyuasin periode Agustus Desember, yakni dari Desa Daya Makmur, Desa Sido Mulyo 18, dan Desa Sumber makmur.

Penelitian ini dilaksanakan pada tanggal 13 Mei - 4 Juni 2019 di Kecamatan Muara Padang Kabupaten Banyuasin. Tepatnya dirumah masing - masing tiap responden, karena peneliti melakukan wawancara dengan mendatangi rumah responden untuk diwawancarai mengenai fenomena pernikahaan dini yang terjadi dilingkungan masyarakat Kecamatan Muara Padang Kabupaten Banyuasin. Setalah didapatkan hasil dari penelitian yang sudah dilaksanakan, data tersebut akan diolah sejak dari awal persiapan langsung kelapangan atau mempersiapkan wawancara kepada masyarakat dan juga observasi disertai dengan dokumentasi sampai terlaksananya penelitian, dimulai 
dari menemukan masalah, data dikelolah untuk dianalisis, menganalisis lebih detail data, meng-coding data, mengurutkan sesuai permasalahan yang ada pada wilayah tersebut, sehingga dapat menarik kesimpulan dan memaknai data. Dengan menggunakan rumus persentase dapat menggambarkan bagaimana hasil mengenai persepsi masyarakat terhadap pernikahan dini di Kecamatan Muara Padang Kabupaten Banyuasin.

\section{Persepsi Masyarakat Pernikahan Usia Dini \\ Tentang}

Pernikahan yang terjadi pada usia yang belum cukup umur bisa menyebabkan banyak permasalahan seperti tingkat emosi di dalam diri yang masih sangat labil, yang sulit untuk bias dikontrol, memiliki sifat egois karena jiwa sebenarnya yang masih kanak-kanak dalam membentuk suatu ikatan rumah tangga yang harmonis. Berikut hasil wawancara dengan 21 reponden yang menikah usia dini dan orang tua yang menikah usia dini terkait persepsi mereka terhadap pernikahan usia dini:

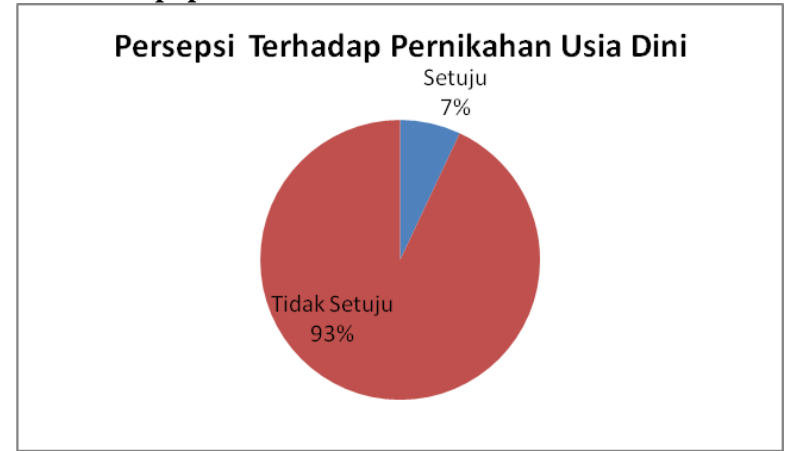

Gambar 1. Persentase Persepsi responden terhadap pernikahan usia dini

Berdasarkan diagram diatas yang dihasilkan dari penelitian melalui wawancara dengan 21 responden dapat dilihat dan disimpulkan bahwasannya persepsi masyarakat yang setuju dengan adanya pernikahan dini hanya 7 Persen, sedangkan yang tidak setuju dengan adanya pernikahan dini yaitu terdiri dari 93 persen. Berikut hasil wawancara terhadap responden:
Menurut Agus Riyanto (38 Tahun) "setujulah, karena saya merasakan pernikahan dini juga".

Menurut Mujiono (41 Tahun) " sangat tidak setuju,karena pernikahan dini itu sering dilakukan di Kecamatan Muara Padang ini, dia tidak memikirkan kedepannya, tentang ekonomi kedepannya, atau keluarga yang menjalankannya, akibatnya seperti apa atas pernikahan dini tersebut".

Menurut Rima (45 Tahun) tidak setuju, tapi mau gimana lagi, mungkin dengan menikah bisa merubah nasib. Dari Hasil wawancara sebagian besar masyarakat tidak setuju dengan pernikahan usia dini mereka menganggap pernikahan usia dini terjadi karena kurangnya pengetahuan remaja dan orang tua tentang dampak negatif pernikahan usia dini, hal ini senada dengan yang di kemukakan oleh (Damayati \& Taufik, 2017) mengatakan pernikahan usia dini pada remaja banyak terjadi akibat ketidak tauhan remaja tentang apa itu pernikahan usia dini dan dampak yang tejadi akibat dari pernikahanusia dini.

Pendapat yang senada juga dikemukan oleh (Erwinsyah \& Supriyadi, 2018) mengenai persepsi masyarakat terhadap penikahan usia dini di Kelurahan Jebres yakni sangat dipengaruhi oleh rendahnya tingkat pendidikan maupun pengetahuan orang tua dan anak menyebabkan adanya kecenderungan mengawinkan anaknya yang masih dibawah umur. Persepsi masyarakat banyak yang tidak setuju namun nyatanya masih banyak yang melakukan pernikahan usia dini, di sini sangat diperlukan peran dari berbagai pihak untuk mengedukasi masyarakat tentang dampak negatif nikah dini.

\section{Persepsi Masyarakat Tentang Penyebab Pernikahan Dini}

Ada banyak faktor yang bisa menyebabkan pernikhan usia dini, namun setiap daerah terkadang mempunyai perbedaan dan persamaan faktor yang 
menyebakan pernikahan usia dini, dalam penelitian ini penulis meneliti beberapa faktor sebagai berikut:

\section{Faktor Pendidikan}

Dari hasil wawancara menggunakan kuesioner didapat persepsi masyarakat tentang pendidikan mempengaruhi pernikahan usia dini atau tidak.

Tabel 3. Persentase jawaban responden dari faktor pendidikan terhadap pernikahan dini

\begin{tabular}{|c|c|c|c|}
\hline Pertanyaan & Jawaban & $\begin{array}{l}\text { Frekue } \\
\text { nsi }\end{array}$ & $\begin{array}{l}\text { Persenta } \\
\text { se }\end{array}$ \\
\hline \multirow{2}{*}{$\begin{array}{l}\text { Bagaimana } \\
\text { Pendapat anda } \\
\text { mengenai } \\
\text { faktor } \\
\text { pendidikan, } \\
\text { apakah } \\
\text { mempengaruhi } \\
\text { pernikahan di } \\
\text { usia dini? }\end{array}$} & $\begin{array}{l}\text { Mempen } \\
\text { garuhi }\end{array}$ & 14 & $100 \%$ \\
\hline & $\begin{array}{l}\text { Tidak } \\
\text { mempen } \\
\text { garuhi }\end{array}$ & 0 & $0 \%$ \\
\hline \multicolumn{2}{|l|}{ Jumlah } & 14 & $100 \%$ \\
\hline
\end{tabular}

Sumber: Hasil Wawancara Tahun 2019

Dari hasil wancara yang didapat $100 \%$ responden mengatakan fakor pendidikan paling berpengaruhi terjadinya pernikahan usia dini, faktor pendidikan merupakan faktor yang sangat penting dan dapat berpengaruh bagi pertumbuhan anak, supaya dapat berpikir lebih baik dan tidak memutuskan untuk melakukan pernikahan di usia dini. Dan Menurut Agustriana (2015:41) rendahnya tingkat pendidikan orang tua, membuat rendahnya pengetahuan terhadap dampak pernikahan dini, baik dampak dari segi hukum, segi psikologis, maupun dari segi biologis anak. Berikut hasil wawancara terhadap salah satu responden

Iskandar (42 Tahun) " Betul pendidikan itu mempengaruhi dan memegang peranan penting adanya pernikahan dini dimasyarakat kita, makanya ketika anak - anak mereka mengenyam pendidikan tinggi maka pemahaman mereka tentang pentingnya berkeluarga dan sebagainya itu mereka menjadi paham, tapi ketika mereka tidak mengenal pendidikan itu, pergaulan diantara mereka juga, maka akan memahami dan berpikiran yasudah dari pada nganggur seperti ini, lebih baik menikah saja, maka dari itu pendidikan itu sangatlah berpengaruh". Pendidikan merupakan hal yang sangat penting untuk membangun sumber daya manusia, dengan pendidikan yang tinggi hal ini bisa memutuskan lingkaran setan yang terjadi pada rumah tangga yang menikah usia dini, untuk itu diperlukan kesadaran dari masyarakat baik orang tua maupun dari remaja itu sendiri akan pentingnya pendidikan.

\section{Faktor Ekonomi}

Faktor ekonomi yang menyebakan pernikahan usia dini hampir terjadi disetiap daerah begitu juga di Kecamatan Muara Padang, berikut hasil data yang didapat:

Tabel 4. Persentase jawaban responden dari faktor ekonomi terhadap pernikahan dini

\begin{tabular}{|l|c|c|c|}
\hline Pertanyaan & Jawaban & Frekuensi & Persentase \\
\hline $\begin{array}{l}\text { Apakah } \\
\text { pernikahan } \\
\text { dini }\end{array}$ & Ada & 11 & $79 \%$ \\
\cline { 2 - 4 } dilakukan \\
$\begin{array}{l}\text { karena } \\
\text { kesulitan } \\
\text { ekonomi } \\
\text { keluarga? }\end{array}$ & $\begin{array}{c}\text { Tidak } \\
\text { ada }\end{array}$ & 3 & $21 \%$ \\
\hline \multicolumn{2}{|c|}{ Jumlah } & 14 & $100 \%$ \\
\hline
\end{tabular}

Sumber: Data Primer Kecamatan Muara Padang Tahun 2019

\section{Sebanyak $\quad 79 \% \quad$ responden} mengatakan pernikahan usia dini terjadi karena adanya kesulitan ekonomi dan 21\% lainya mengatakan tidak ada unsur kesulitan ekonomi. Faktor ekonomi masih menjadi alasan para pelaku pernikahan usia dini untuk menikah pada usia yang sangat muda, hal ini senada dengan yang diungkapkan oleh Agustian (2013) dikutip dari Arianti (2018) perkawinan usia muda terjadi karena keadaan keluarga digaris kemiskinan, untuk meringankan beban orang tuanya maka wanitanya dikawinkan dengan orang yang dianggap mampu. Adapun hasil wawancara yang dilakukan 
kepada salah satu responden yaitu sebagai berikut:

Khomsin (49 Tahun) " kebanyakan pas-pasan, jadi kesulitan ekonomi itu ada".

Harwanto (47 Tahun) " tidak ada kesulitan ekonomi keluarga”.

Nashirudin (30 Tahun) " kebanyakan kurang mampu, dan kesulitan ekonomi sehingga anak nya mau melakukan pernikahan dini demi meringankan beban orang tua dalam menyari nafkah.

Menurut (Singh dan Samarah, 1996) Kemiskinan dan tingkat ekonomi orang tua mempengaruhi usia anak untuk menikah, semakin tinggi tingkat ekonomi orang tua memperlambat merkan untuk menikahkan anak perempuanya pada usia dini. Dengan memperbaiki perekonomian masyarakat maka penyakit-penyakit sosial akan berkurang termasuk pergaulan bebas yang akan berdampak hamil diluar nikah dan pernikahan pada usia muda yang tidak di inginkan.

3. Faktor Kebudayaan

Di negara berkembang seperti Indonesia masih banyak kebudayaan yang didapat secara turun temurun yang didapat dari orang tua akan di ikut oleh anaknya dalam berbagai macam aspek kehidupan, mulai dari mata pencarian, dalam bidang seni, termasuk juga usia menikah. Berikut hasil penelitian yang di dapat:

Tabel 5. Pengaruh Faktor Kebudayaan Terhadap Pernikah Usia Dini

\begin{tabular}{|l|c|c|c|}
\hline Pertanyaan & Jawaban & $\begin{array}{c}\text { Frekue } \\
\text { nsi }\end{array}$ & $\begin{array}{c}\text { Perse } \\
\mathrm{n}\end{array}$ \\
\hline $\begin{array}{l}\text { Bagaimana } \\
\text { pendapat anda } \\
\text { apakah tradisi } \\
\text { suku-suku di } \\
\text { daerah anda ada } \\
\text { yang } \\
\text { mempengaruhi } \\
\text { tingkat } \\
\text { pernikahan usia } \\
\text { dini? }\end{array}$ & $\begin{array}{c}\text { Mempeng } \\
\text { aruhi }\end{array}$ & 6 & $43 \%$ \\
\hline \multicolumn{2}{|c|}{$\begin{array}{c}\text { Tidak } \\
\text { aruhi }\end{array}$} & 8 & $57 \%$ \\
\hline
\end{tabular}

Sumber: Hasil Wawancara di Kecamatan Muara Padang Tahun 2019
Sebanyak $\quad 57 \% \quad$ responden mengatakan faktor kebudayan tidak mempengaruhi pernikahan usia dini. Kecamatan Muara Padang merpakan daerah transmigrasi yang sebagian besar penduduknya merupakan penduduk pendatang dari berbagai wilayah di Indonesia terutama dari Pulau Jawa. Responden mengungkapkan tentang persepsinya mengenai suku - suku yang ada di Kecamatan Muara Padang yakni kebanyakan dari suku jawa barat atau lebih dikenal dengan sebutan Sunda yang masih melakukan pernikahan dini atau usia belum cukup umur. Berikut hasil wawancara yang telah dilakukan kepada salah satu responden yaitu sebagai berikut:

Winarko (35 Tahun ) " Ada suku tertentu yang memang sering melakukan pernikahan dini terhadap anaknya, mayoritas disini di Kecamatan Muara Padang yang sering melakukan pernikahan dini adalah suku dari jawa barat".

Zuhroh (22 Tahun) "Sebagian ada yang memang tahu sebelumnya seperti itu karena tradisi atau pun suku-suku tertentu yang melakukan pernikahan dini atau pernikahan dibawah umur. Tetapi karena sekarang sudah zaman modern ya jadi gak begitu berpengaruh tradisi atau suku suku didaerah ini".

Seperti pendapat (Mahfudin dan Waqi'ah, 2016) maksut adat dan budaya adalah adat dan budaya perjodohan yang masih umum dan terjadi di beberapa daerah di Indonesia. Dimana anak gadis sejak kecil telah dijodohkan oleh orang tuanya, dan segera dinikahkan sesaat setelah anak menstruasi. Umumnya anak menstruasi diusia kurang lebih 12 tahun. Namun seiring dengan perkembangan zaman budaya perjodohan orang tua tidak lagi banyak terjadi di Kecamatan Muara Padang, hal in dapat dilihat sebanyak 57\% responden mengatakan bahwa pernikah usia dini tidak dipengaruhi oleh kebudayan tertentu. 


\section{Persepsi Masyarakat Tentang Dampak Pernikahan Dini}

Penikahan dini tentu membawah dampak terhadap kehidupan rumah tangga yang menikah usia dini. Dalam penelitian ini penulis akan melihat tentang persepsi masyarakat tentang dampak pernikah usia dini dilihat dari dampak terhadap kehidupan ekonomi:

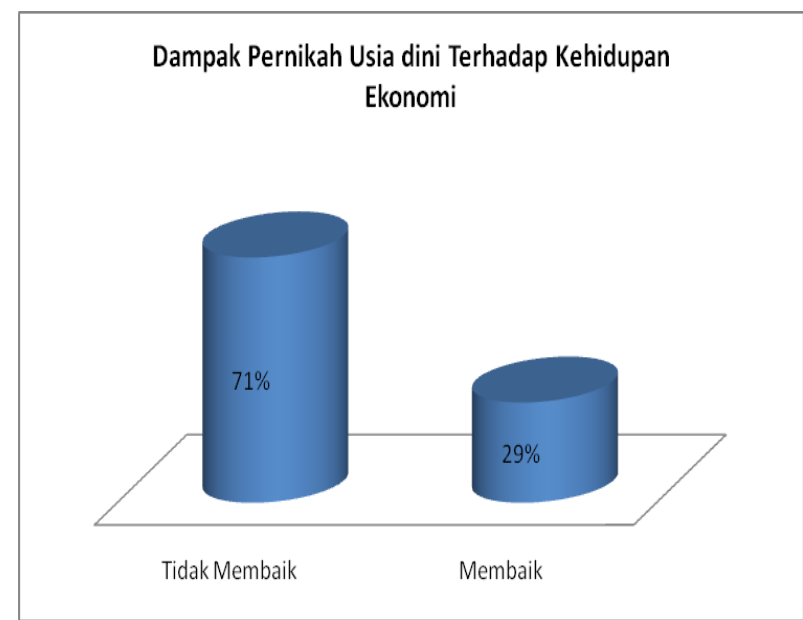

Gambar 2. Persepsi dampak pernikahan usia dini terhadap kehidupan Ekonomi

Dari hasil penelitian sebanyak $71 \%$ reponden mengatakan pernikahan usia dini tidak memperbaiki keadaan ekonomi rumah tangga yang menikah usia dini, hal ini dapat dilihat masih banyaknya pasangan yang menikah usia dini tinggal atau berada di rumah orang tua, pekerjaan yang tidak jelas, penghasilan kecil dan tidak menentu pula. Berikut hasil wawancara terhadap responden mengenai persepsinya yaitu sebagai berikut:

Mastini Rahayu (22 Tahun) “ Tidak ada perbaikan ekonomi pada keluarga yang melakukan pernikahan dini. Tetapi jika dibandingkan dengan yang menikah diusia dewasa ya pasti ada perbedaannya dengan yang menikah diusia dini dan juga Pasti lebih baik ekonomi yg menikah dewasa".

Sa'diyah (25 Tahun) " Perbaikan yang signifikan itu tidak ada, malahan kebanyakan masih tinggal dengan orang tuanya, tetapi apa bila di bandingkan dengan menikah yang lebih dewasa, tentu mengalami perbedaan yang sangat jauh dimana akan lebih matang dan lebih mengalami perbaikan ekonomi yang sudah melakukan pernikahan dewasa.

Masroni (47 Tahun) "ada perbaikan ekonomi, selain berpisah dari orang tuanya anak mulai belajar dalam mencari nafkah untuk menghidupi keluarganya".

Dibandingkan dengan wanita yang menikah pada usia dewasa, wanita yang menikah sebagai anak-anak secara sosial rentan disebabkan kemiskinan, tidak berpendidikan, tinggal di daerah pedesaan dan memiliki sedikit akses ke pelayanan kesehatan (Nasrullah, Muassam, Bhutta, \& A, 2014). Ada dua hal yang mempengaruhi perceraian yaitu pernikahan usia dini dan kemandulan (Tilson \& Larsen, 2000). Sedangkan menurut (Mahfudin dan Waqi'ah, 2016) banyak sekali orang yang telah melangsungkan pernikahan tidak begitu penting untuk memikirkan masalah apa saja yang mungkin terjadi setelah menjalani hidup sebagai pasangan suami istri khususnya bagi pasangan yang menikah pada usia muda, dengan ketidaksiapan membuat banyak rumah tangga yang menikah usia dini berakhir dengan perceraian. Jadi dapat disimpulkan bahwa pernikahan usia dini bukan merupakan solusi untuk memperbaiki ekonomi, melainkan akan timbul masalah baru lagi yang lebih berbahaya.

\section{SIMPULAN}

Hasil penelitian yang didapatkan mengenai persepsi masyarakat terhadap pernikahan dini yang ada di Kecamatan Muara Padang Kabupaten Banyuasin menyatakan bahwa 93\% masyarakat mengatakan tidak setuju jika suatu pernikahan dilakukan di usia dini. Namun demikian hal tersebut masih saja terjadi karena kurangnya pendidikan, kesulitan ekonomi dan sebagian kecil lainya dikarenakan kebudayaan yang ada dilingkungan masyarakat tersebut. Selain itu juga dampak pernikah usia dini dapat memperbaiki ekonomi juga tidak mengalami perubahan justru pernikahan 
usia dini menimbulkan masalah baru dalam pasangan yang menikah dini.

Berdasarkan hasi penelitian yang diperoleh maka untuk mengatasi permasalah pernikahan usia dini diharapkan peran serta semua lapisan masyarakat dimulai dari lingkungan keluarga agar membentuk keluarga kecil,sehat, sejatera, dan bahagia agar anak-anak tidak mencari kebahagian dengan mengenal lawan jenis pada usia yang sangat muda. Selain itu juga peran tokoh masyarakat dan pemerintah sangat diperlukan seperti mengedukasi masyarakat tentang dampak pernikahan usia dini dan merevisi undang-undang perkawinan no. 1 Tahun1974 tentang batas minimal usia kawin.

\section{DAFTAR PUSTAKA}

Agustriana, Fatma., Angriani, Parida. (2015) Persepsi Pelajar Sekolah Menengah Atas (SMA)Terhadap Pernikahan Usia Dinidi Kecamatan Banjarmasin Selatan Kota Banjarmasin. JPG (Jurnal Pendidikan Geografi) Volume 2, No 4, 38 - 49 e-ISSN : 2356-5225

Arianti, Desi, Winda. (2018). Persepsi Remaja Tentang Pernikahan Dini Di SMA Pesantren Guppi Samata KecamatanSomba Opu Kabupaten Gowa

BPS. (2018). Kabupaten Banyuasin Dalam Angka 2018. Pangkalan Balai: Badan Pusat Statistik.

Council on Foreign Relations (CFR). Ending Child Marriage: How Elevating the Status of Girls Advances U.S. Foreign Policy Objectives , p.6.

Damayati, Nina (2013). Pernikahan Usia Dini dan Implikasinya Terhadap Keberlangsunga RumahTangga di Kecamatan Sungai Keruh Kabupaten Musi Banyuasin. Tesis S2. Ilmu Kepndudukan, Universitas Gadjah Mada

Damayati, Nina (2016). Faktor-Faktor Yang Mempengaruhi Pernikahan Usia Dini di Kecamatan Sungai Keruh Kabupaten Musi Banyuasin. Jurnal Swarnabhumi. Vol 1 (1) 72-79

Damayati, Nina., Taufik, Mirna. (2017). Persepsi Siswa Terhadap Pernikahan Usia Dini di SMA Negeri 2 Sungai Keruh. Jurnal Dosen Universitas PGRI Palembang.

Erwinsyah, A., \& Supriyadi. (2018). Persepsi Masyarkat Terhadap Pernikahan Usia Dini di Kelurahan Jebres Kecamatan Jebres Kota Surakerta. Analisis Sosiologi, 7 (1), 27-42.

Grogger, J. And Bronars, S., (1993). The socioeconomics consequences of teenage chilbearing: findings from a Natural Experiment. Family Planing Perspective, 25 (4): 156-161

Mahfudin, Agus., Waqi'ah, Khoirotul. (2016). Pernikahan Dini dan Pengaruhnya Terhadap Keluarga diKabupaten Sumenep Jawa Timur. Jurnal Hukum Keluarga Islam Volume 1, Nomor 1, April 2016; ISSN: 2541-1489.

Noviyanti, E,.(2019). Faktor-Faktor Penyebab Pernikahan Dini Di Desa Tulus Ayu Kecamatan Belitang Madang Raya Kabupaten Oku Timur.

Nasrullah, M., Muassam, S., Bhutta, \& A, R. (2014). Girl Child Marriage and its effect on Fertility in Pakistan: Findings From Pakistan Demographic and Health Survey 2006-2007. Matern Child Health , 534-543.

Singh. S., dan Samara. R., (1996). Early marriage among women in Development Countries. Fam Plan Perpect, 22 (4) 148-157 \& 175

PAI. (2018). Profil Anak Indonesia 2018. Jakarta: Kementerian Pemberdayaan Perempuan dan Perlindungan Anak (KPPPA).

Tilson, \& Larsen. (2000). Divorce In Ethiopia: The Impact Of Early Marriage And Childlessnes. Jurnal of Biosocial Science, 355-372.

Wilopo. (2005). Kita Selamatkan Remaja dari Aborsi dalam Rangka Pemantapan Keluarga Berkualitas. RAKERNAS BKKBN. Medan: BKKBN. 